\title{
Trends in Antarctic ozone hole metrics 2001-17
}

\author{
Matthew B. Tully ${ }^{\mathrm{A}, \mathrm{E}}$, Paul B. Krummel and Andrew R. Klekociuk $^{\mathrm{C}, \mathrm{D}}$ \\ A Bureau of Meteorology, GPO Box 1289, Melbourne, Vic. 3001, Australia. \\ ${ }^{B}$ Climate Science Centre, CSIRO Oceans and Atmosphere, Aspendale, Vic., Australia. \\ ${ }^{C}$ Antarctica and the Global System, Australian Antarctic Division, Kingston, ACT, Australia. \\ DAntarctic Climate and Ecosystems Cooperative Research Centre, Hobart, Tas., Australia. \\ ${ }^{\mathrm{E}}$ Corresponding author. Email: matt.tully@bom.gov.au
}

\begin{abstract}
Linear trends over the years 2001-17 are reported of a number of standard metrics used to describe the severity of the Antarctic ozone hole, both with and without a simple adjustment to account for meteorological variability. The trends were compared to those from the years 1979-2001. All metrics considered showed a trend towards reduced ozone depletion since 2001, at significance levels ranging from 2.4 to 3.9 standard errors of the trend after the adjustment was performed. The adjustment for meteorological variability had little effect on the values of the trends but did substantially reduce the scatter and, therefore, uncertainty of the trends.
\end{abstract}

Received 22 January 2018, accepted 13 May 2019, published online 11 June 2020

\section{Introduction}

It has been recognised for many years (Schoeberl et al. 1996; Newman and Nash 2000; Newman et al. 2004, 2006) that although stratospheric halogen concentration (the essential cause of the Antarctic ozone hole) is the dominant driver of decadal-scale variability in Antarctic ozone, the year to year variation is mostly due to stratospheric dynamics. Colder temperatures in the polar stratosphere in austral winter and spring are associated with a more stable polar vortex, a greater volume of polar stratospheric clouds, fuller and more widespread chlorine activation and thus a deeper and longer lasting ozone hole. Temperature variations should, therefore, be taken into account when assessing ozone hole variations over time, particularly, systematic temperature changes that could be induced by increasing greenhouse gas emissions or radiative feedback from the ozone hole itself (Solomon et al. 2017).

Apart from polar temperature, there do exist a number of additional factors which also contribute to interannual ozone hole variability. These include the transport of chlorine to the poles (Strahan et al. 2014), which has been shown to be modulated by the equatorial Quasi Biennial Oscillation (Strahan et al. 2015), and increased stratospheric aerosol amounts resulting from large volcanic eruptions (Ivy et al. 2017; Stone et al. 2017). The contribution of very short-lived halogenated substances has also been recently studied (Yang et al. 2014; Sinnhuber and Meul 2015; Oman et al. 2016; Fernandez et al. 2017; Falk et al. 2017; Hossaini et al. 2017). Further, trends in ozone hole metrics can also be affected by nonlinear saturation effects (Bodeker 2002; Newman et al. 2006; Yang et al. 2008). However, it is shown below that temperature alone can account for the majority of the interannual variability.
Using a variety of approaches and selections of data, recent work has attempted to establish the existence of a statistically significant decrease in ozone depletion over Antarctica which can be attributed to declining halogen levels (Kuttippurath et al. 2013; Knibbe et al. 2014; de Laat et al. 2015; Solomon et al. 2016; Kuttippurath and Nair 2017; de Laat et al. 2017; Strahan and Douglass 2018; Pazmino et al. 2017; Keeble et al. 2017).

Here, we consider four representative metrics reported on in the series of papers by Klekociuk et al. (2011, 2014a, 2014b, 2015) and Tully et al. (2008, 2011): maximum 15-day averaged ozone hole area, minimum 15-day averaged total column ozone, integrated ozone deficit and the duration of the ozone hole. For each of the four metrics, we compute the linear trend over the time period 2001-17. We then adjust each metric for meteorological variability, using a simple linear fit to an appropriate choice of temperature time series from the MERRA-2 reanalysis, and recompute the trends after adjustment. For comparison, we also compute the linear trends over the earlier 1979-2001 period using the same approach.

\section{Methods}

The four Antarctic ozone hole metrics have been calculated using total column ozone measurements from the Total Ozone Mapping Spectrometer (TOMS) series of instruments on a number of satellite platforms, the Ozone Monitoring Instrument (OMI) onboard the Aura satellite and the Ozone Mapping Profiler Suite (OMPS) on Suomi National Polar-orbiting Partnership satellite. These measurements now span the years 1979 2017; however, no data are available for 1995 and only limited 

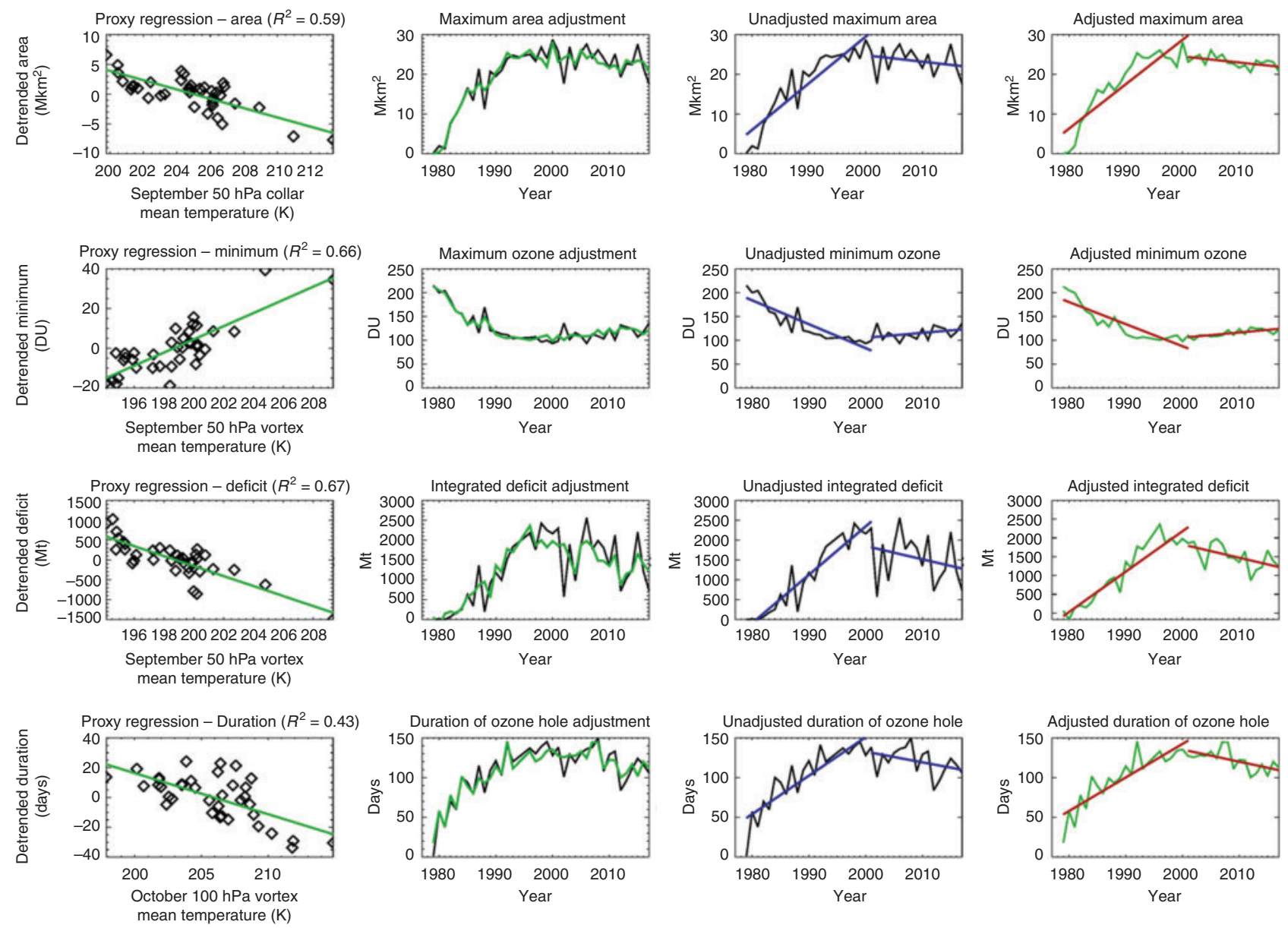

Fig. 1. For each of the four metrics - maximum 15-day averaged area of ozone hole, minimum 15-day averaged total column ozone, integrated ozone deficit and duration of ozone hole - scatter plot of detrended metric vs selected temperature proxy and the linear fit (green); the adjusted (green) and unadjusted (black) proxy time series; linear 1979-2001 and 2001-17 trends (blue) of the unadjusted time series; linear 1979-2001 and 2001-17 trends (red) of the adjusted time series.

data for 1994. OMI data have been used here for 2005 in preference to TOMS which was also in operation at the same time.

Temperature values are taken from the MERRA-2 reanalysis (Gelaro et al. 2017), as made available from the NASA Ozone Watch website (http://ozonewatch.gsfc.nasa.gov/, accessed 21 April 2020). For each of the metrics considered, linear correlations were established between monthly mean temperatures in either the 'vortex' $\left(60-90^{\circ} \mathrm{S}\right)$ or the 'collar' $\left(55-75^{\circ} \mathrm{S}\right)$ regions, and the detrended 1979-2017 time series for each metric. The detrending was performed by subtracting the record of each metric from a smoothed version of itself obtained with a LOESS smoothing (11-point window). (Alternative methods of producing a smoothed representative curve would serve equally well for the purpose of detrending.)

We select temperature parameters as shown below that were best correlated with the individual ozone hole metrics, although it should be noted that there is generally a high degree of correlation between polar temperatures at different heights, latitude ranges and months of the year, meaning that different choice of temperature parameters would give similar results to those presented here:

- Maximum 15-day averaged area - September $50 \mathrm{hPa}$ collar mean $\left(R^{2}=0.59\right)$

- Minimum 15-day averaged total column ozone - September $50 \mathrm{hPa}$ vortex mean $\left(R^{2}=0.66\right)$

- Integrated ozone deficit - September $50 \mathrm{hPa}$ vortex mean $\left(R^{2}=0.67\right)$

- Duration of ozone hole - October $100 \mathrm{hPa}$ vortex mean $\left(R^{2}=0.43\right)$

Scatter plots for the four correlations are shown in Fig. 1. The simple linear fit to temperature is able to explain up to two-thirds of the variance, in the case of ozone hole mass deficit. The weakest correlation is found for ozone hole duration, which is influenced by temperature in early winter as well as late spring.

Independent linear trends are derived following Steinbrecht et al. (2017) and Chipperfield et al. (2017) rather than alternatives such as piecewise linear or fits to equivalent effective 
Table 1. Linear trends of the four metrics, both adjusted and unadjusted for temperature, with uncertainty expressed as two standard errors, for the time periods 1979-2001 and 2001-17

\begin{tabular}{|c|c|c|c|c|}
\hline Metric & 1979-2001 trend & 1979-2001 trend (adjusted) & $2001-17$ trend & 2001-17 trend (adjusted) \\
\hline Minimum 15 day averaged total column ozone (DU year ${ }^{-1}$ ) & $-5.00 \pm 1.16$ & $-4.62 \pm 1.16$ & $1.03 \pm 1.26$ & $1.08 \pm 0.55$ \\
\hline Duration of ozone hole (days year ${ }^{-1}$ ) & $4.84 \pm 1.22$ & $4.22 \pm 1.07$ & $-1.34 \pm 1.66$ & $-1.52 \pm 1.05$ \\
\hline
\end{tabular}
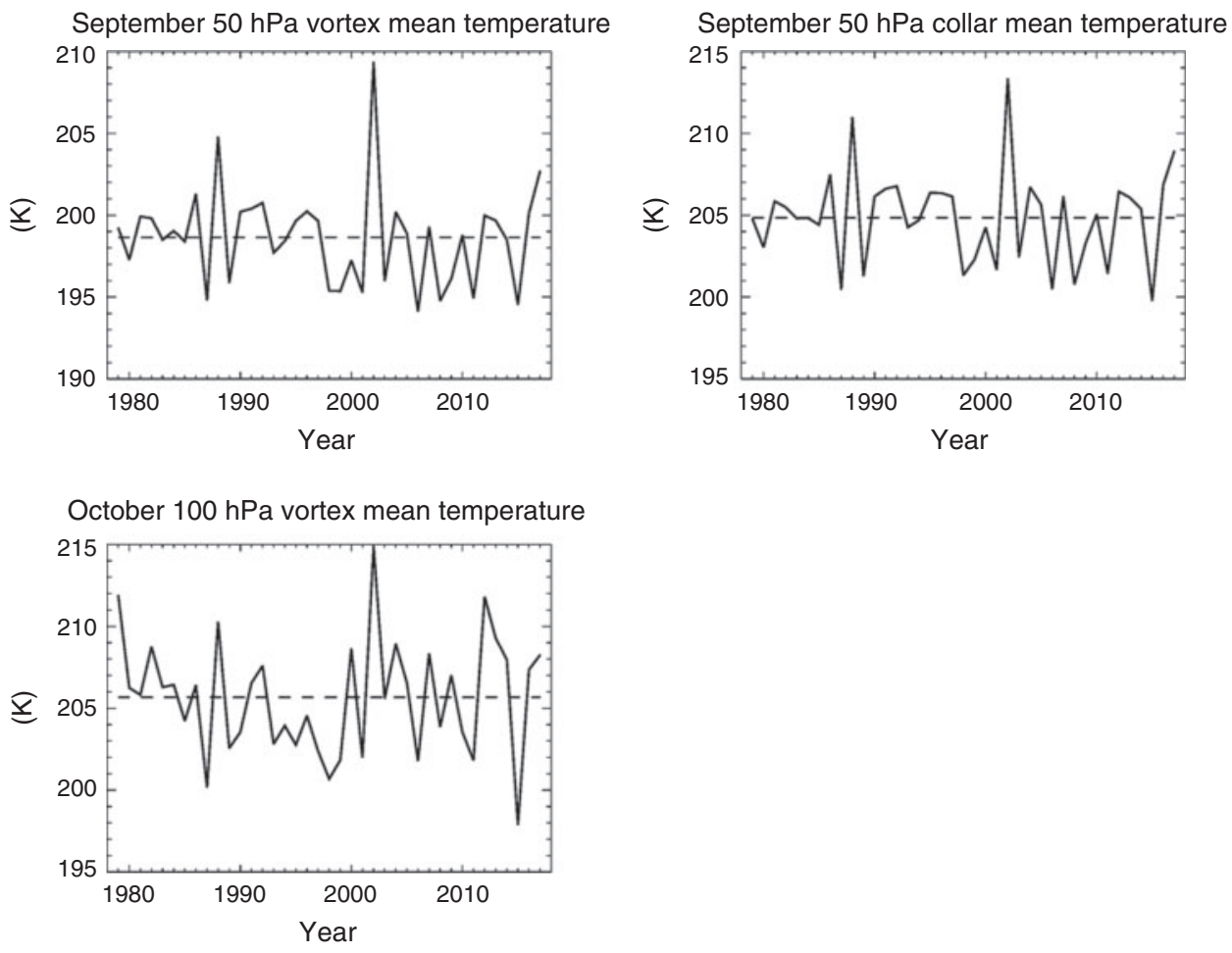

Fig. 2. Mean temperature in the polar vortex at $50 \mathrm{hPa}$ for September (upper left panel), for the vortex collar at $50 \mathrm{hPa}$ in September (upper right panel) and polar vortex mean at $100 \mathrm{hPa}$ in October (lower left panel). The dashed line represents the mean over the 1979-2017 period.

stratospheric chlorine (EESC). Since the ozone hole was particularly severe in the year 2000 with respect to most metrics, a conservative choice has been made to consider only the 2001-17 trends.

Figure 1 shows, for each of the four metrics, the fit to the chosen temperature proxy, the proxy time series with and without adjustment according to the fit, and then 1979-2001 and 2001-17 trends with and without adjustment. Table 1 gives the values of the resulting trends with uncertainty limits of two standard errors. Auto-correlation of the residuals is minimal, less than 0.2 for all four metrics, resulting in negligible effect on the significance of the trends.

Figure 2 shows time series of the polar temperatures used in the regressions. The magnitude of temperature variability is noticeably greater in October, which supports the preferred use of September to establish ozone trends specifically related to ozone depleting substance decline (Solomon et al. 2016). Although the sign of the temperature fluctuations (i.e., whether a year is warmer or cooler than the long-term average) is generally consistent between the 2 months, the relative magnitudes can differ somewhat, such as in 2012. For both months, the interannual variability is significantly greater than longterm changes.

For all four metrics considered, the calculated trend since 2001 is in the direction of increased ozone (or equivalently, reduced ozone depletion). The reduction of scatter following adjustment for meteorological variability substantially increases the significance of the trends, at levels ranging from 2.4 to 3.9 standard errors. The magnitude of the trends, however, is not greatly affected by the temperature adjustment, attributable to the lack of any large systematic changes in temperature over this period. 
For the earlier 1979-2001 period, the linear trend of decreasing ozone is significant at a much higher significance level than the ozone increase in the second period. Neither the magnitude nor uncertainty of the 1979-2001 trends is very dependent on the temperature adjustment. It is evident in Fig. 1 that the quality of the fit is limited more by the nonlinearity of the metrics in the early and later years than the inter-annual scatter. Although all four metrics displayed significant change over this period, the rate of change was not constant. This is to be expected, since the growth rate of stratospheric chlorine, represented by EESC (Newman et al. 2006), slowed considerably by the end of the century due to the success of the Montreal Protocol. Further, the use of a threshold (220 DU) to define the ozone hole metrics also necessarily introduces nonlinearity in the early years, seen most clearly in ozone hole area and ozone hole duration.

\section{Conclusions}

Linear trends, over the years 2001-17 of four standard metrics used to describe the severity of the Antarctic ozone hole, have been presented, both with and without a simple adjustment to account for meteorological variability. The simple linear fit of each metric to a selected Antarctic temperature proxy is able to account for the majority of the interannual variability in the metrics related to ozone hole area, minimum value of ozone, and integrated ozone mass deficit, but not ozone hole duration.

Adjusting the metrics for temperature substantially increases the significance of the observed trends. However, the magnitude of trends is not greatly dependent on whether the adjustment has been applied. For all four metrics considered, trends of reduced ozone depletion over the 2001-17 period become significant at the 2 standard error level once the temperature adjustment has been performed, but not without.

For comparison, the linear trends in each metric of the earlier period 1979-2001 have also been calculated, which are highly significant regardless of temperature adjustment.

The method of analysis employed is clearly limited to identifying a significant increase or decrease in ozone, and not establishing the underlying physical cause, apart from excluding meteorological variability. However, the ratios of pre- to post2001 trends given in Table 1 are quite consistent, within uncertainties, with the ratio of increase and decrease of stratospheric chlorine loading in Antarctica, which for these time ranges is estimated as -4 .

\section{Acknowledgements}

We acknowledge the Australian Government Department of the Environment and Energy for support of this work. The TOMS, OMI and OMPS data used in this study are provided by the NASA Goddard Space Flight Center, Atmospheric Chemistry \& Dynamics Branch, Code 613.3. MERRA2 data were obtained from the NASA ozone watch website (https://ozonewatch. gsfc.nasa.gov/, accessed 21 April 2020). This research did not receive any specific grant funding.

\section{References}

Bodeker, G. E. (2002). Dynamical containment of Antarctic ozone depletion. Geophys. Res. Lett. 29(7), 1098. doi:10.1029/2001GL014206

Chipperfield, M. P., Bekki, S., Dhomse, S., Harris, N. R. P., Hassler, B., Hossaini, R., Steinbrecht, W., Thiéblemont, R., and Weber, M. (2017).
Detecting recovery of the stratospheric ozone layer. Nature 549(7671), 211-218. doi:10.1038/NATURE23681

de Laat, A. T. J., van der A, R. J., and van Weele, M. (2015). Tracing the second stage of ozone recovery in the Antarctic ozone-hole with a "big data" approach to multivariate regressions. Atmos. Chem. Phys. 15(1), 79-97. doi:10.5194/ACP-15-79-2015

de Laat, A. T. J., van Weele, M., and van der A, R. J. (2017). Onset of stratospheric ozone recovery in the Antarctic ozone hole in assimilated daily total ozone columns. J. Geophys. Res.: Atmos. 122(21), 11,88011,899. doi:10.1002/2016JD025723

Falk, S., Sinnhuber, B.-M., Krysztofiak, G., Jöckel, P., Graf, P., and Lennartz, S. T. (2017). Brominated VSLS and their influence on ozone under a changing climate. Atmos. Chem. Phys. 17, 11313-11329. doi:10. 5194/ACP-17-11313-20172017

Fernandez, R. P., Kinnison, D. E., Lamarque, J.-F., Tilmes, S., and Saiz-Lopez, A. (2017). Impact of biogenic very short-lived bromine on the Antarctic ozone hole during the 21 st century. Atmos. Chem. Phys. 17(3), 1673-1688. doi:10.5194/ACP-17-1673-2017

Gelaro, R., McCarty, W., Suárez, M. J., Todling, R., Molod, A., Takacs, L., Randles, C., Darmenov, A., Bosilovich, M. G., Reichle, R. H., Wargan, K., Coy, L., Cullather, R. I., Akella, S. R., Bachard, V., Conaty, A. L., da Silva, A., Gu, W., Koster, R. D., Lucchesi, R. A., Merkova, D., Partyka, G. S., Pawson, S., Putman, W. M., Rienecker, M. M, Schubert, S. D., Sienkiewicz, M. E., and Zhao, B. (2017). The modern-era Retrospective analysis for Research and Applications, Version 2 (MERRA-2). J. Clim. 30(14), 5419-5454. doi:10.1175/JCLI-D-16-0758.1

Hossaini, R., Chipperfield, M. P., Montzka, S. A., Leeson, A. A., Dhomse, S. S., and Pyle, J. A. (2017). The increasing threat to stratospheric ozone from dichloromethane. Nat. Commun. 8, 15962. doi:10.1038/NCOMMS15962

Ivy, D. J., Solomon, S., Kinnison, D., Mills, M. J., Schmidt, A., and Neely, R. R., III (2017). The influence of the Calbuco eruption on the 2015 Antarctic ozone hole in a fully coupled chemistry-climate model. Geophys. Res. Lett. 44, 2556-2561. doi:10.1002/2016GL071925

Keeble, J., Brown, H., Abraham, N. L., Harris, N. R. P., and Pyle, J. A. (2017). On ozone trend detection: using coupled chemistry-climate simulations to investigate early signs of total column ozone recovery. Atmos. Chem. Phys. 18, 7625-7637. doi:10.5194/ACP-18-7625-20182018

Knibbe, J. S., van der A, R. J., and de Laat, A. T. J. (2014). Spatial regression analysis on 32 years of total column ozone data. Atmos. Chem. Phys. 14(16), 8461-8482. doi:10.5194/ACP-14-8461-2014

Klekociuk, A. R., Tully, M. B., Alexander, S. P., Dargaville, R. J., Deschamps, L. L., Fraser, P. J., Gies, H. P., Henderson, S. I., Javorniczky, J., Krummel, P. B., Petelina, S. V., Shanklin, J. D., Siddaway, J. M., and Stone, K. A. (2011). The Antarctic ozone hole during 2010. Aust. Meteorol. Oceanogr. J. 61, 253-267. doi:10.22499/2.6104.006

Klekociuk, A. R., Tully, M. B., Krummel, P. B., Gies, H. P., Petelina, S. V., Alexander, S. P., Deschamps, L. L., Fraser, P. J., Henderson, S. I., Javorniczky, J., Shanklin, J. D., Siddaway, J. M., and Stone, K. A. (2014a). The Antarctic ozone hole during 2011. Aust. Meteorol. Oceanogr. J. 64, 293-311. doi:10.22499/2.6404.006

Klekociuk, A. R., Tully, M. B., Krummel, P. B., Gies, H. P., Alexander, S. P., Fraser, P. J., Henderson, S. I., Javorniczky, J., Petelina, S. V., Shanklin, J. D., Schofield, R., and Stone, K.A. (2014b). The Antarctic ozone hole during 2012. Austr. Meteorol. Oceanogr. J. 64, 313-330. doi:10.22499/ 2.6404.007

Klekociuk, A. R., Tully, M. B., Krummel, P. B., Gies, H. P., Alexander, S. P., Fraser, P. J., Henderson, S. I., Javorniczky, J., Shanklin, J. D., Schofield, R., and Stone, K. A. (2015). The Antarctic ozone hole during 2013. Austr. Meteorol. Oceanogr. J. 65, 247-266. doi:10.22499/2.6502.005

Kuttippurath, J., Lefèvre, F., Pommereau, J. -P., Roscoe, H. K., Goutail, F., Pazmiño, A., and Shanklin, J. D. (2013). Antarctic ozone loss in 19792010: first sign of ozone recovery. Atmos. Chem. Phys. 13(3), 16251635. doi:10.5194/ACP-13-1625-2013 
Kuttippurath, J., and Nair, P. J. (2017). The signs of Antarctic ozone hole recovery. Sci. Rep. 7(1), 585. doi:10.1038/S41598-017-00722-7

Newman, P. A., and Nash, E. R. (2000). Quantifying the wave driving of the stratosphere. J. Geophys. Res.: Atmos. 105(D10), 12485-12497. doi:10. 1029/1999JD901191

Newman, P. A., Kawa, S. R., and Nash, E. R. (2004). On the size of the Antarctic ozone hole. Geophys. Res. Lett. 31(21), L21104. doi:10.1029/ 2004GL020596

Newman, P. A., Nash, E. R., Kawa, S. R., Montzka, S. A., and Schauffler, S. M. (2006). When will the Antarctic ozone hole recover? Geophys. Res. Lett. 33(12). doi:10.1029/2005GL025232

Oman, L. D., Douglass, A. R., Salawitch, R. J., Canty, T. P., Ziemke, J. R., and Manyin, M. (2016). The effect of representing bromine from VSLS on the simulation and evolution of Antarctic ozone. Geophys. Res. Lett. 43(18), 9869-9876. doi:10.1002/2016GL070471

Pazmino, A., Godin-Beekmann, S., Hauchecorne, A., Claud, C., Khaykin, S., Goutail, F., Wolfram, E., Salvador J., and Quel, E. (2017). Symptoms of total ozone recovery inside the Antarctic vortex during Austral spring. Atmos. Chem. Phys. 18, 7557-7572. doi:10.5194/acp-18-755720182018

Schoeberl, M. R., Douglass, A. R., Kawa, S. R., Dessler, A. E., Newman, P. A., Stolarski, R. S., Roche, A. E., Waters, J. W., and Russell, J. M., III (1996). Development of the Antarctic ozone hole. J. Geophys. Res.: Atmos. 101(D15), 20909-20924. doi:10.1029/96JD01707

Sinnhuber, B.-M., and Meul, S. (2015). Simulating the impact of emissions of brominated very short lived substances on past stratospheric ozone trends. Geophys. Res. Lett. 42(7), 2449-2456. doi:10.1002/ 2014GL062975

Solomon, S., Ivy, D. J., Kinnison, D., Mills, M. J., Neely, R. R., III, and Schmidt, A. (2016). Emergence of healing in the Antarctic ozone layer. Science 353(6296), 269-274. doi:10.1126/science.aae0061

Solomon, S., Ivy, D., Gupta, M., Bandoro, J., Santer, B., Fu, Q., Lin, P., Garcia, R. R., Kinnison, D., and Mills, M. (2017). Mirrored changes in Antarctic ozone and stratospheric temperature in the late 20th versus early 21st centuries. J. Geophys. Res.: Atmos. 122(16), 8940-8950. doi:10.1002/2017JD026719

Steinbrecht, W., Froidevaux, L., Fuller, R., Wang, R., Anderson, J., Roth, C., Bourassa, A., Degenstein, D., Damadeo, R., Zawodny, J., Frith, S., McPeters, R., Bhartia, P., Wild, J., Long, C., Davis, S., Rosenlof, K., Sofieva, V., Walker, K., Rahpoe, N., Rozanov, A., Weber, M., Laeng, A., von Clarmann, T., Stiller, G., Kramarova, N., Godin-Beekmann, S., Leblanc, T., Querel, R., Swart, D., Boyd, I., Hocke, K., Kämpfer, N.,
Maillard Barras, E., Moreira, L., Nedoluha, G., Vigouroux, C., Blumenstock, T., Schneider, M., García, O., Jones, N., Mahieu, E., Smale, D., Kotkamp, M., Robinson, J., Petropavlovskikh, I., Harris, N., Hassler, B., Hubert, D., and Tummon, F. (2017). An update on ozone profile trends for the period 2000 to 2016. Atmos. Chem. Phys. 17(17), 10675-10690. doi:10.5194/acp-17-10675-2017

Stone, K. A., Solomon, S., Kinnison, D. E., Pitts, M. C., Poole, L. R., Mills, M. J., Schmidt, A., Neely, R. R. , III, Ivy, D., Schwartz, M. J., Vernier, J.-P., Johnson, B. J., Tully, M. B., Klekociuk, A. R., König-Langlo, G., and Hagiya, S. (2017). Observing the impact of Calbuco volcanic aerosols on South Polar ozone depletion in 2015. J. Geophys. Res.: Atmos. 122(21), 11862-11879. doi:10.1002/2017JD026987

Strahan, S. E., Douglass, A. R., Newman, P. A., and Steenrod, S. D. (2014). Inorganic chlorine variability in the Antarctic vortex and implications for ozone recovery. J. Geophys. Res.: Atmos. 119(24), 14098-14109. doi:10.1002/2014JD022295

Strahan, S. E., Oman, L. D., Douglass, A. R., and Coy, L. (2015). Modulation of Antarctic vortex composition by the quasi-biennial oscillation. Geophys. Res. Lett. 42(10), 4216-4223. doi:10.1002/2015GL063759

Strahan, S. E., and Douglass, A. R. (2018). Decline in Antarctic ozone depletion and lower stratospheric chlorine determined from aura microwave limb sounder observations. Geophys. Res. Lett. 45, 382-390. doi:10.1002/2017GL074830

Tully, M. B., Klekociuk, A. R., Deschamps, L. L., Henderson, S. I., Krummel, P. B., Fraser, P. J., Shanklin, J. D., Downey, A. H., Gies, H. P., and Javorniczky, J. (2008). The 2007 Antarctic ozone hole. Austr. Meteorol. Mag. 57, 279-298.

Tully, M. B., Klekociuk, A. R., Alexander, S. P., Dargaville, R. J., Deschamps, L. L., Fraser, P. J., Gies, H. P., Henderson, S. I., Javorniczky, J., Krummel, P. B., Petelina, S. V., Shanklin, J. D., Siddaway, J. M., and Stone, K. A. (2011). The Antarctic ozone hole during 2008 and 2009. Austr. Meteorol. Oceanogr. J. 61, 77-90. doi:10.22499/ 2.6101 .007

Yang, E. -S., Cunnold, D. M., Newchurch, M. J., Salawitch, R. J., McCormick, M. P., Russell, J. M., III, Zawodony, J. M., and Oltmans, S. J. (2008). First stage of Antarctic ozone recovery. J. Geophys. Res. 113(D20), D20308. doi:10.1029/2007JD009675

Yang, X., Abraham, N. L., Archibald, A. T., Braesicke, P., Keeble, J., Telford, P. J., Warwick, N. J., and Pyle, J. A. (2014). How sensitive is the recovery of stratospheric ozone to changes in concentrations of very short-lived bromocarbons? Atmos. Chem. Phys. 14(19), 10431-10438. doi:10.5194/acp-14-10431-2014 